\title{
Erratum to: On Finite Mixture Modeling of Change-Point Processes
}

\author{
Xuwen $\mathrm{Zhu}^{1} \cdot$ Yana Melnykov ${ }^{1}$ \\ Published online: 16 September 2021 \\ (C) The Classification Society 2021
}

\section{Erratum to: Journal of Classification \\ https://doi.org/10.1007//s00357-021-09385-6}

The original version of this article unfortunately contained some mistake at reference Sarkar et al., 2020. Thus, this is corrected as follows:

The original paper has been corrected.

\section{Reference}

Sarkar, S., Zhu, X., Melnykov, V., \& Ingrassia, S. (2020). On parsimonious models for modeling matrix data. Computational Statistics \& Data Analysis, 142, 106822.

Publisher's Note Springer Nature remains neutral with regard to jurisdictional claims in published maps and institutional affiliations.

The online version of the original article can be found at https://doi.org/10.1007/s00357-021-09385-6

\section{Xuwen Zhu}

xzhu20@cba.ua.edu

Yana Melnykov

ymelnykov@cba.ua.edu

1 Department of Information Systems, Statistics, and Management Science, University of Alabama, Tuscaloosa, AL 35487, USA 